\title{
THE IMPACT OF SMALL AND MEDIUM SIZED ENTERPRISES IN THE DEVELOPMENT OF HEALTH TOURISM IN MACEDONIA
}

\author{
УТИЦАЈ МАЛИХ И СРЕДЫИХ ПРЕДУЗЕһА НА РАЗВОЈ ЗДРАВСТВЕНОГ \\ ТУРИЗМА У МАКЕДОНИЈИ
}

\author{
Marija Magdincheva Shopova \\ University Goce Delchev, Stip, Macedonia \\ Faculty of Tourism and Business Logistics ${ }^{1}$
}

Kiril Postolov

Ss. Cyril and Methodius University in Skopje,

Faculty of Economics- Skopje, Macedonia ${ }^{2}$

Aleksandra Janeska Iliev

Ss. Cyril and Methodius University in Skopje, Faculty of Economics- Skopje, Macedonia ${ }^{3}$

Dusko Joshevski

University Goce Delchev, Stip, Macedonia

Faculty of Tourism and Business Logistics ${ }^{4}$

\begin{abstract}
Апстракт: Узимајући у обзир теоријски приступ проучавања алтернативних облика туризма, основни ичиљ овог радасастоји се уистраживању концепта здравственог туризма као облика алтернативног туризма,истовремено разматрајући специфичне карактеристике здравственог туризма, како на страни понуде, тако и на страни тражње. Надаље, различити аспекти треба да представљају везу између туризма и здравља, као структуралног елемента ове расправе.

У емпиријском делу рада, спроведено је истраживање које има за цииь да побољша разумевање чињеничног стања у контексту малих и средњих предузећа (МСП). Стога, спремност предузећа да понуде потребне услуге у сегменту здравственог туризма, као и различите повезане пословне активности, попут финансирања и иновација. У том контексту, у раду се потврђује основна хипотеза да развој здравственог туризма у земљи зависи од присуства малих и средњих предузећа која су иницијатори снабдевања у сектору здравственог туризма. На основу резултата истраживања предложен је концепт за даљи развој здравственог туризма

Кључне речи: мала и средња предузећа, здравствени туризам, понуда здравственог туризма, предузетници, потребе туриста
\end{abstract}

Abstract: Considering the theoretical approach of studying alternative forms of tourism, this paper main objective is investigating the concept of health tourism as a form of alternative tourism, at the same time discussing specific characteristics of health tourism

\footnotetext{
${ }^{1}$ marija.magdinceva@ugd.edu.mk

${ }^{2}$ kirilp@eccf.ukim.edu.mk

3 aleksandra.janeska@eccf.ukim.edu.mk

${ }^{4}$ dusko.josevski@ugd.edu.mk
} 
both at the side of supply and demand. Furthermore, the different aspects should present links between tourism and health, as a structural element of this discussion.

In the empirical section of the paper, a practical research is conducted that aims to improve the understanding of the factual situation in light of small and medium sized enterprises (SMEs),. Hence, the readiness of enterprises to offer the required services in the segment of health tourism, as well as different related business activities to such, as financing and innovations. In this context the paper confirms the basic hypothesis that the development of health tourism in the country depends upon the presence of small and medium sized enterprises, which are initiators of supply in the sector of health tourism. Based on the results of the survey a concept for the for the further development of health tourism is proposed

Key words: small and medium sized enterprises, health tourism, health tourism supply, entrepreneurs, needs of tourists

\section{INTRODUCTION}

Tourism is a sector that encourages economic development and has a major role in the creation of the labour market and the founding of enterprises in the tourism sector; especially enterprises specialized for certain services. Tourism has always been seen as a process of selfregeneration as well as relaxation, education and indulgence (Smith, Puczko, 2014).

The market related to the so called 'health tourism' consists of supply and demand of services related to the health sector usually by consumers from abroad. There are a number of studies that suggest a correlation between the health sector and tourism (Michalos, et al., 2000).

The health-tourism market is mainly generated by the relationship between tourism and health as two independent areas. In the classic sense, health and tourism have differing aims of existence. Whereas tourism is mainly a result of social and entertaining nature, health services have been dominantly recognized as elemental needs of consumers. However this type of market is formed because of the emerging need of consumers, integrating the main characteristic of both activities, but predominantly under the influence of costs and availability.

The precondition for the development of health tourism is a competitive supply and offer of lower pricing for various health services that are part of the tourist offer. In this line it should be stressed that small and medium sized enterprises (SMEs) are considered to be key factors for the growth and development of the tourism industry globally.

Nowadays small and medium sized enterprises (SMEs) are the driving force of modern business processes. The characteristics of small enterprises, reflected in the ability for customization and rapid introduction of new types of business, contribute an increasing efficiency 
and creation of optimal tourist supply, simultaneously boosting the development of health tourism.

\section{HEALTH TOURISM - FORM OF ALTERNATIVE TOURISM IN THE REPUBLIC OF MACEDONIA}

The development of alternative forms of tourism is particularly important in areas where there is an authentic nature, cultural heritage, and health institutions associated with the recreational opportunities, cultural experiences and entertainment. Certain authors (Goodrich, Goodrich, 1994) defined health tourism as "the attempt on the part of a tourist facility or destination to attract tourists by deliberately promoting its health care services and facilities, in addition to its regular tourist amenities. In terms of health tourism, activities and services related to tourism activities, combined with the appropriate medical service where benefits of this type of tourism are important to society, especially the local population living in areas suitable for these forms of tourism. Benefits should be sought in various areas. Health tourism offers opportunities to use supply sustainably using and promoting different aspect where needed. In terms of health, tourism is marked as the human need, which occurs because of the modern lifestyle.

Health tourism, or the practice of traveling to a tourist destination with the main purpose of receiving some therapeutic treatment or medical service, is an attempt to discover new calmer, ways of life and work. Almost all modern tourist developments include certain activities. Tourism is a set of relationships and phenomena arising from the travel and stay of foreigners in one place, which of course does not mean permanent settlement especially if they are not tied to economic activity.

Health tourism is a combination of appropriate treatment or use of a service-related treatment or health care in the form of surgery, dental procedures, spa treatment, and alternative medicine and so on considering adequate tourist services. Health tourism refers to the travel of individuals from their residences elsewhere in order to obtain treatment (Altın, Bektaş, Antep, İrban, 2012)

Most modern tourist developments related to health services or predominantly the concept of health tourism is defined as the provision of health facilities to use the country's natural resources, especially mineral water and climatic conditions. 


\section{HEALTH-TOURISM SUPPLY AND DEMAND}

Health tourism is a special form of tourism. In this respect, health tourism is associated with a certain tour in order to receive the needed medical service or treatment. Health tourism often is related to certain existing natural resources and adequate facilities that potentially could offer various types of health services. Only competitive and appropriate touristic offers could improve the quality of touristic facilities and promote the development of enterprises belonging to this sector.

The demand related to health tourism is created by tourists and customer service which are willing to use health and tourism services because of their needs. Adequate tourist supply is always altered to meet certain demand. Although supply is in function of demand, still among tourist supply and demand there is an unpredictable connection which cannot be always anticipated. The purpose of the supply is not only to meet the existing needs and preferences of potential consumers, i.e. tourists, but also to initiate the creation of new needs and requirements of consumers. Consumers in the health care sector are different and very complicated in comparison to consumers in other sectors. The users in the health care group include external customers such as patients, family members of patients, potential customers, and home users such as employees and employer (Lee, Lee, Kang, 2012).

They are looking for products and services with defined quality satisfying theirs needs. They recognize and acquire optimal quality accepting only if products or services meet their needs (Tomić, et.al, 2016, p. 4).

Some managers active in the tourism or hospitality industry, act as if today profit is primary and at the same time customer satisfaction is second. However this certainly could not be in any case true in the medical sector. Good managers prefer to satisfy their customers, consequently customers shall pay a fair financial compensation for the acquired products or services. Hence it is considered that a fair price should include a certain profit margin for the firm (Kotler, Bowen, Makens, 2013, p. 7).

Knowing the needs of tourists is very important both from theoretical and practical aspect. However it could distinguished that especially the needs in the segment of health tourism are unique. They do not constitute the necessity needs at some points but represent a type of recognisable need. Tourism requirements as specific needs are not essential but belong to secondary or additional needs. Given that health tourism needs are the target of organized and targeted social activities seeking to please specific needs that are important on different levels. 
The impact of small and medium sized enterprises in the development...

The demand for health services is initiated by the needs of tourists. The tourist supply side contains services offered by enterprises related to economic and non-economic activities, that directly or indirectly participate in meeting the needs of domestic and foreign tourists. Certain health tourism needs, can be satisfied only if they contain a greater number of individual and diverse goods that will be synchronized in a complete product in the segment of tourism. To meet the diverse needs of consumers, tourists require presence of a large number of entities participating in the development of the tourist supply.

Needs are motives that affect people and encourage certain activities and tours. Health services and treatments that are synchronized with interesting tourist attractions also represent an opportunity for rest and relaxation for the visitors and an essential element for the development of health tourism. The need for people to travel temporarily outside the country of their primary residence, for using a particular medical service differs from the usual trip. That changes the motive of tourist movements. Accelerating urbanization and hence, the popularization of tourism, in particular affects the following factors: economic factors, technical factors, social factors, factors of an institutional nature and factors of psychological and irrational nature.

\section{SMALL AND MEDIUM SIZED ENTERPRISES AS A BASIC PREREQUISITE FOR THE DEVELOPMENT OF HEALTH TOURISM IN MACEDONIA}

The development of health tourism in the Republic of Macedonia depends on the establishment of certain conditions, that facilitate the manner of practicing this concept, as an opportunity for development and realization of revenue. The development concept of health tourism can be realized through constant monitoring of the work processes, evaluation of the specific needs of tourists, supply, demand and providing conditions to satisfying the specific needs on time and place.

Health tourism is an area with high potential for growth and development as a result of the customers, i.e potential tourists who constantly have new needs expressed by predefined medical treatment or services. This form of tourism is the least developed form and is in the phase of market introduction (Kesar, Rimac, 2011)

The basic prerequisite for the development of health tourism is presented in the opportunities offered by small and medium sized enterprises (SMEs), as resources that can offer good access increasing the supply side of adequate medical treatment, active leisure, recreation and entertainment.

Vol. 19, број 1/2017, cmp. 69-79 
The presence of small and medium sized enterprises (SMEs) in the sector of health tourism is important in terms of recognizing and taking advantage of market opportunities and innovation of entrepreneursowners. The enterprises involved in the region related to entrepreneurship, constantly adjust their conception of work in accordance to the challenges of the processes of globalization and economic integration. The successful operation of enterprises is based upon the constant introduction of new ways and forms of work considering the characteristic of small and medium sized enterprises (SMEs).

The representation of small and medium sized enterprises (SMEs) in the sector of health tourism is important in terms of recognizing and taking advantage of market opportunities and the ability to quickly create the optimal tourism supply.

On the other hand, small and medium sized enterprises (SMEs) must apply an innovative approach to creating health offer (services and treatments) and various matters that are part of the tourist offer. They accelerate innovative creativity, risk taking and organizational learning whereas the basic characteristics of the conservative culture are controlled, including numerous rules and risk avoidance (Atuahene-Gima and Ko. A., 2001).

Therefore enterprises involved in this segment need to apply entrepreneurial facets and constantly adapt the concept of work, challenging the needs of the consumer-tourists.

\section{EFFECTS AND OPPORTUNITIES OFFERED BY SMALL AND MEDIUM SIZED ENTERPRISES (SMES) FOR THE DEVELOPMENT OF HEALTH TOURISM}

Small businesses are an important segment in overall economic activities. This segment constantly changes things, moves and develops. The emergence and development of small enterprises in the past twenty years is closely related to the expressed economic and development dimensions and democratic social processes, which are usually associated with entrepreneurship and entrepreneurial initiative. Small and medium sized enterprises (SMEs) are some of the key factors for growth of the tourism industry globally.

Small enterprises have recognized the unique advantage associated with efficient, informal communications systems, high degrees of market adaptability, by introducing relatively cheaper innovations. The relationship of health activity and modern tourism is perceived by factors 
that initiate the development of tourism and health, and economic benefits arising because of the development of tourism and health.

The economic benefits of health tourism can be expressed through direct and indirect effects. Direct economic effects are realized directly through the enterprises in the field of health, through the sale and realization of health tourism services. They are measurable and expressed through the realized difference in revenues and expenditures offered and sold services.

The indirect economic effects are manifested in various forms of tourist trade, generating tourists that acquire health services. This is the main motive for the arrival, presence and stay in a particular tourist destination. Indirect economic influences considering health tourism are expressed through motivation for the selection of adequate tourist destination are: extending the tourist season throughout the whole year, increasing outside consumption and promotion of the diversity and quality of the tourism offer.

Advantages, which are specific for small businesses need to be used in order to enrich the tourist offer and the development of health tourism. It is necessary to encourage the process of creation of small and medium sized enterprises that would offer a completely new line of products and services in the field of health tourism. Health and recreational facilities, small business offering rehabilitation services and treatment, spa and fitness centres, small businesses active in the service industry based on internet technology oriented towards promoting a health tourism offer, furthermore small business active as travel agencies to animate the people who use certain medical services, and offering daily engagements for the full implementation of free time, are only some of the aspects where small business is vested in the health tourism sector.

\section{METHODOLOGY AND RESEARCH RESULTS}

Empirical research in this paper is implemented in order to perceive the actual terms related to the willingness of companies to offer the required health tourism services, the type of business activities to be undertaken, aspects related to financing of business activities and providing necessary resources. The survey was conducted among 45 companies that perform health and tourist activity in the period from 01.01.2016 to 31.12.2016. Through the method of the questionnaire consisting of ten questions. Hence of the surveyed 45 companies, 42 have indicated interest in participating in the survey and respondent to the questions. 
According to the results of the survey performed among enterprises that implement health-tourist activities and the total number of observations received on each question concluded, the sample examined consists of 42 companies.

Considering the first question considering whether respondents 'have information for the customers' needs related to certain health services?', most of the surveyed enterprises or exactly 36 responded that they had no specific information about market needs. Furthermore the in light of type of services that consumers need only 6 enterprises responded that they have certain information, but are not sufficiently capable to follow the needs of consumers.

On the next question as to the need of institutional support to improve the work in the sector of health tourism? The majority or 35 enterprises responded that they need the support and cooperation and only 7 enterprises do not need any type of help and support in this respect.

The third question is focused on whether respondents think that they have an adequate supply of services and treatments. Mainly a greater number of enterprises responded positive, 29 enterprises have introduced a list of products and services offering to consumers lists of medical services, and 13 enterprises have not introduced in any way medical products and services.

The fourth question relates to what respondents think related to the development of health tourism depending upon on the introduction of an adequate supply in this sector? (Synchronized health tourism offer), Hence managers of all 42 enterprises responded that the development of health tourism sector depends on the introduction of appropriate health tourism supply.

The next question relates on how to finance the introduction of new business processes. Hence 38 enterprises responded that financing operations is mainly executed by credit lines and programs and only 4 enterprises have been financing investments and new forms of work organization by own funds.

The next question in respect to bringing additional resources to expand the offer in the field of health tourism. Most if the surveyed enterprises or 39 enterprises responded that they need additional resources in order to create a supply in the sector of health tourism.

The question where it should indicate whether there is a readiness to invest in the field of health tourism?, Hence 34 respondents responded that they want to invest in the field of health tourism but are restricted by finances and 7 enterprises have responded that they are willing to invest.

In the seventh question attentions in oriented toward introducing new products and services in the field of health tourism. Most of the 
enterprises or 37 responded that they can't introduce new products and services due to lack of awareness and limited financing and whereas 5 enterprises have expressed willingness to invest in introducing new products and services.

In the question whether the responded needs appropriate programs for education and training in the field of health tourism all surveyed managers expressed the need for education programs in the field of health tourism.

The last question - What are the limiting factors for investment in the field of health tourism?, The majority of the surveyed or more precisely 37 managers responded that the low level of information and limited finances are prohibitive for investment in this sector.

The results from the survey, confirms the hypothesis that the development of health tourism in Republic of Macedonia depends on the existence of small and medium sized enterprises (SMSs), which would be able to create a synchronized competitive offering referring to medical and tourist services. In terms of the readiness of companies to offer the necessary health tourism services, considering the type of business activities, financing and introduction of innovations it could be concluded that most of the surveyed enterprises had low level of information on market needs, in addition to the lack of appropriate institutional support for promotion of the sector of the medical tourism.

The management of most of the surveyed enterprises considered that the development of health tourism depends on the introduction of appropriate health tourism offerings. Restrictive factors in the development of health tourism is the reluctance to introduce new products and services, due to lack of awareness and limited financing. Most of the companies surveyed have programs for training and education of employees, although management indicated a need of specialized education in the field of health tourism and the introduction of education programs in this area.

\section{CONCLUSION}

The development of the alternative forms of tourism comes from the modern tendencies in the world, hence development various types of tourism such as sport tourism, active tourism etc,. Tourism and health iare two highly related socio-economic occurrences in every modern society. Interrelationship between tourism and health comes from the consideration of factors that initiate the development of health tourism at the same time reaping off the economic benefits that rise as an output from the development of health tourism. Hence the development of the 
health tourism in R. Macedonia depends upon the assurance of certain preconditions. The basic precondition for the development of health tourism is the existence of SME's. They are the driving force of the economic development and a key factor from the aspect of creating opportunities for the development for the development of local, regional and national level. As driver of development, small and medium sized enterprises are able to respond to the customer demands, flexible in executing their business activities, financing and introducing new forms of conduct and innovations. Hence, they are efficient in a business manner and creation of an optimal tourist offer. From the results from the research, one hypothesis was confirmed that the development of health tourism in Republic of Macedonia relies strongly the existence of small and medium sized enterprises, which will be able to create a synchronized offer of the specific medical-tourist services. Results also indicate that enterprises are not well informed about the possibilities for growth that are provided by the sector of health tourism and market needs. Unpreparedness of the enterprises to introduce new products and services due to lack of information and limited financing are restrictive factors considering the development of health tourism.

\section{LITERATURE}

1. Altın, U., Bektaş, G., Antep, Z., İrban, A. (2012). The International Patient's Portfolio and Marketing of Turkish Health Tourism, Procedia - Social and Behavioral Sciences, Vol. 58, 1004-1007

2. Atuahene-Gima, K., Ko., A. (2001). An empirical investigation of the effect of market orientation and entrepreneurship orientation alignment on product innovation, Organization Science, 12(1), 5474

3. Drucker, P. (2005). Управување во новото општество. Нови Сад: Адижес.

4. Goodrich, J.N. (1994). Health tourism: A new positioning strategy for tourist destinations, Journal of International Consumer Marketing, 6 (3-4), 227-237.

5. Kesar, O., Rimac, K. (2011). Medical Tourism Development in Croatia, International Review of Economics and Business, 14(2), 107-134

6. Kotler, P., Bowen, J., Makens, J. (2013). Marketing for Hospitality and Tourism, 6 edition, Pearson. 
7. Kraus, S., Kauranen, L. (2009). Strategic management and entrepreneurship: Friends or foes?, Int. Journal of Business Science and Applied Management, 4(1), 37-50

8. Lee, S. M., Lee, D., Kang, C.-Y. (2012). The impact of highperformance work systems in the health-care industry: employee reactions, service quality, customer satisfaction, and customer loyalty, The Service Industries Journal, 32(1), 17-36.

9. Michalos, A.C., Zumbo, B.D., Hubley, A. (2000). Health and the Quality of life, Social Indicators Research, 51(3), 245-286

10. Smith, M., László Puczkó (2014). Health, Tourism and Hospitality: Spas, Wellness and Medical Travel, Routledge.

11. Томић, С., Лековић, К., Дакић, С. (2016). Квантитативна анализа лојалности потрошача туристичкој дестинацији, Економски погледи, 18(4), 1-10

12. Wellness and Tourism: Mind, Body, Spirit, Place (Innovation and Tourism, Connecting Theory \& Practice), Human Kinetics; 13 edition 2013, Thomas Sawyer (Editor).

Рад је примљен: 27.02.2017.

Коригована верзија примљена: 02.03.2017.

Рад је прихваћен за итампање: 06.03.2017. 